\title{
Quality control in the different stages of producing red blood cell concentrate from dogs
}

\author{
[Controle de qualidade nas diferentes etapas de produção do concentrado de \\ hemácias em cães] \\ M.N.A. Marchi ${ }^{1}$, P.E. Luz $^{2}$, R.R. Martins ${ }^{1}$, S.M. Simonelli ${ }^{3}$, \\ U.P. Pereira ${ }^{3}$, P.M. Pereira ${ }^{3}$ \\ ${ }^{1}$ Aluno de pós-graduação - Universidade Estadual de Londrina - Londrina, PR \\ ${ }^{2}$ Clínica Veterinária - Londrina, PR \\ ${ }^{3}$ Universidade Estadual de Londrina - Londrina, PR
}

\begin{abstract}
The objective of this study was to perform a quality control assessment of red blood cells after standardization of the blood production stages. For this purpose, separation of the blood components to obtain red blood cells, the storage of the blood packets and an evaluation of blood quality were performed. The mean $( \pm$ SD) volume, globular volume, hemoglobin and hemolysis percentage of the red blood cell concentrate were $299.77 \pm 30.08 \mathrm{~mL}, 60.87 \pm 2.60 \%, 20.57 \pm 0.93 \mathrm{~g} / \mathrm{DL}$ and $0.09 \pm 0.07 \%$, respectively. The means $( \pm \mathrm{SD})$ of the volume, globular volume, total hemoglobin percentage of hemolysis and hemoglobin per unit of packed red blood cells after the storage period ( $8.83 \pm 6.73$ days) were $57.55 \pm 3.01 \%, 20.30 \pm 0.890,20 \pm 0.12 \%$, and $60.90 \pm 7.65$. The red blood cell packets were within the parameters of quality control established by Health Ministry legislation in humans and allow us to conclude that the standardization of blood production stages involves the selection of donors until the end of storage and is necessary to produce quality red blood cells. Quality control aims to find possible flaws in the procedures to be repaired, increasing transfusion safety.
\end{abstract}

Keywords: blood bank, blood components, transfusion medicine

\section{RESUMO}

O objetivo deste estudo foi realizar o controle de qualidade do concentrado de hemácias após a padronização das etapas de produção do sangue. Para isso, realizou-se separação de hemocomponentes para obtenção de concentrado de hemácias, armazenamento das bolsas de sangue e avaliação da qualidade delas. Os valores médios $( \pm D P)$ do volume, do volume globular, da hemoglobina e do

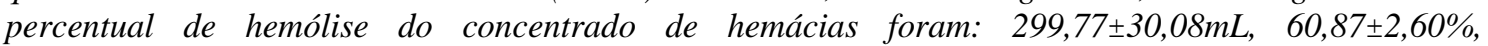
$20,57 \pm 0,93 \mathrm{~g} / \mathrm{DL}$ e $0,09 \pm 0,07 \%$, respectivamente. Os valores médios $( \pm D P)$ do volume globular, da hemoglobina total percentual de hemólise e da hemoglobina por unidade de concentrado de hemácias

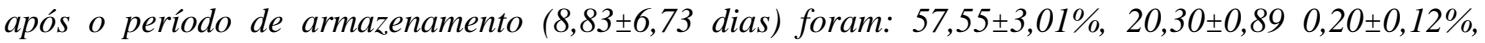
$60,90 \pm 7,65$. As bolsas de concentrado de hemácias ficaram dentro dos parâmetros de controle de qualidade estabelecidos pela legislação do Ministério da Saúde em humanos e possibilitaram concluir que a padronização das etapas de produção do sangue envolve desde a seleção de doadores até o final do armazenamento e é necessária para produzir concentrado de hemácias com qualidade. $O$ controle de qualidade visa encontrar possíveis falhas nos procedimentos para que estas possam ser reparadas, aumentando, assim, a segurança transfusional.

Palavras-chave: banco de sangue, hemocomponentes, medicina transfusional

Recebido em 3 de julho de 2017

Aceito em 11 de julho de 2018

E-mail: melcavet@hotmail.com 


\section{INTRODUCTION}

Advances in blood transfusion in veterinary medicine and the use of blood components have made this practice more common, leading to an increase in the number of veterinary blood banks and a greater concern for the quality of the blood products offered (Barros, 2011).

Previous studies in transfusion medicine have been mainly concerned with the blood receptor, but a successful transfusion also depends on the good health of the blood donor and the quality of the blood components. Therefore, it is essential to use safe components, obtained according to standardized protocols, to minimize the damage to the red blood cells and reduce the risk of transfusion reactions (Ferreira et al., 2014).

The total blood and the red blood cell concentrate are the most commonly used blood components in dogs. Although the best procedures for blood collection, processing and storage of canine red blood cells have been reported by several authors, some critical points that involve all stages of the blood cycle can still be identified, such as the selection of a donor with some infectious disease, bacterial contamination during harvesting, and inadequate blood processing leading to hemolysis (Ford and Mazzaferro, 2006; Abrams-Ogg and Schneider, 2012).

According to Ferreira et al. (2014), human blood banks have rigorous quality control over the blood components to identify nonconformities during blood collection, processing and storage. In veterinary medicine, there is no guideline for well-established quality control protocols. Even today, human parameters are used as a reference in the evaluation of the quality of the blood bags (Barros, 2011; Marchi et al., 2015). The objective of this study was to perform a quality control assessment of red blood cells after standardization of the blood production stages.

\section{MATERIALS AND METHODS}

The project was previously approved by the animal ethics committee (CEUA), registered under $\mathrm{n}^{\mathrm{o}}$ 74989.2015.74. Before beginning the blood collection, a manual of the procedures was elaborated for the Laboratory of Transfusion
Medicine of the State University of Londrina Veterinary Hospital (Dainese and Nunes, 2007). Thirty blood bags from donor dogs were collected from April to September of 2016. The animals were chosen according to age, behavior, weight, anamnesis, physical examination and laboratory tests.

The donor dogs were between 2 and 8 years old, they were docile and calm, accepting physical restraint, and they weighed more than $28 \mathrm{~kg}$ without being obese. They were physically healthy, had no skin lesions or complaints of disease by their guardians, and had no change in blood counts or biochemical tests, such as urea, creatinine, alkaline phosphatase, alanine aminotransferase, albumin, total protein, and glucose. In addition, the polymerase chain reaction (PCR) tests for Erlichia sp. and Babesia $s p$ and serology for Leishmania $s p$ were negative.

A trichotomy was performed in the jugular vein area followed by antisepsis with gauze and a $2 \%$ degermant of a chlorhexidine solution $+70 \%$ alcohol for three minutes. The blood collection bag used was the triple with SAG-M (Sodium chloride, mannitol, monohydrate dextrose and adenine) Fresenius ${ }^{\circledR}$ brand. Bags with a minimum volume of $300 \mathrm{~mL}$ and a maximum of $450 \mathrm{~mL}$ of blood were collected. The first milliliters of blood were diverted to the compartment attached to the bag for testing. The dogs were not anesthetized, only physically contained. Before and after the blood drawing, the donors were awarded with dog treats.

Immediately after the collection of the total blood bag, homogenization was performed, and a sample was collected for globular volume and hemoglobin. All the blood bags were placed on a cold, clean surface for 1 hour until centrifugation.

The blood was fractionated to obtain two blood components, including a concentrate of red blood cells and frozen plasma. For this, the $4200 \mathrm{x} g$ centrifugation protocol was used for 10 minutes at 22 degrees Celsius with settings of nine for the acceleration and five for the deceleration in the Heraeus Cryofuge 5500i - Thermo Scientific ${ }^{\circledR}$ centrifuge.

The separation of the blood components was performed with the Hemoblu® manual plasma 
extractor. Right after the SAG-M preservative solution $(100 \mathrm{~mL})$ was added to the red blood cell concentrate. The bag was homogenized for removal of a sample for globular volume analysis (VG), total hemoglobin (HB) and extracellular hemoglobin.

The red cell concentrate was stored in a common cooler (Pratice 230 - Consul@) exclusively for this purpose until the moment of blood transfusion. Due to the high demand for transfusions, the bags were being used when requested in the hospital routinely. Therefore, bags stored from 4 hours to 28 days $(8.83 \pm 6.73$ days) were evaluated. During the storage time, the refrigerator temperature was checked using a maximum and minimum thermometer once a day. The temperature was adjusted as necessary and was maintained between $2^{\circ} \mathrm{C}$ and $6^{\circ} \mathrm{C}$.

The laboratory tests used to evaluate the quality of the red cell concentrate bags were based on the Collegial Board Resolution - RDC $\mathrm{n}^{\circ} .34$ of June 11, 2014 of the Ministry of Health (MS).

The mass of the total blood and red cell concentrate was obtained by subtracting the weight of the anticoagulant bags from the final value of the weighted bags with blood (in grams). The volume in milliliters was obtained by dividing the blood mass by its density, which was 1,053 for the total blood (Kakaiya et al., 2011) and 1,065 for the red blood cells (Sakuma et al., 2011).

The globular volume and total hemoglobin $(\mathrm{g} / \mathrm{dl})$ values were obtained using the hematological apparatus (Poch 100iv Diff). The determination of the hemoglobin amount in $g$ per red blood cell concentrate was performed using the following calculation: $\mathrm{Hb}(\mathrm{g} / \mathrm{CH})=\mathrm{Hb}(\mathrm{g} / \mathrm{dl}) \times \mathrm{Vol}(\mathrm{dl})$ (Sakuma et al., 2011).

To assess the extracellular hemoglobin, the supernatant plasma was removed after a $1252 \mathrm{x} g$ centrifugation for 10 minutes. The sample was read on an Evolution $60 \mathrm{~S}$ - Thermo Scientific ${ }^{\circledR}$ spectrophotometry apparatus using distilled water as white at a 1:10 dilution. Spectrophotometric readings were performed at
370, 415, 510, 577 and 600nm. (Toulmond et al., 1990).

The hemolysis percentage, in units of red blood cell concentrate and total blood, was determined using a mathematical formula employing hematocrit, extracellular hemoglobin and total hemoglobin (g/DL) as follows: \% Hemolysis = (100 - Ht x Hbe)/Hb (Tomczak, 2008).

The microbiological analysis of the bags of red cell concentrate was performed using the aerobic and anaerobic Hemobac $₫$ triphasic blood culture kit. The hemoculture of the bags was also performed in BHI liquid (Brain Heart Infusion, Neogen Corporation $®)$ in a $1: 5$ proportion $(5 \mathrm{~mL}$ of blood to $45 \mathrm{~mL}$ of the liquid) before and at the end of the blood transfusion.

The data were tested for normality by the Shapiro Wilks test. A regression analysis was performed for the variables of the red blood cell concentrate in relation to the volume. The data on the red cells after the storage period were studied by a regression analysis in relation to storage time. A $5 \%$ error probability was considered for all analyzes using the $\mathrm{R}$ computational package for data analysis.

\section{RESULTS AND DISCUSSION}

Several racial groups were used in the project (Figure 1), and all dogs were within the expected patterns. The average and standard deviation of the weight and age were $35.04 \pm 4.40 \mathrm{~kg}$ and $4.30 \pm 1.60$ years, respectively.

The average and standard deviations of the total blood bag volumes and the red cell concentrates are shown in Table 1. Ferreira et al. (2014) collected 235 bags of dog blood, in which the average volume of the total blood bags was $349 \mathrm{~mL}$, ranging from $218 \mathrm{~mL}$ to $580 \mathrm{~mL}$. In the same study, bags with a volume less than $300 \mathrm{~mL}$ were collected from dogs weighing $15 \mathrm{~kg}$ to $25 \mathrm{~kg}$, removing $13 \%$ to $15 \%$ of blood from the animal and adjusting the proportional amount of anticoagulant of the bag $(63 \mathrm{~mL}$ of anticoagulant to $450 \mathrm{~mL}$ of blood). 


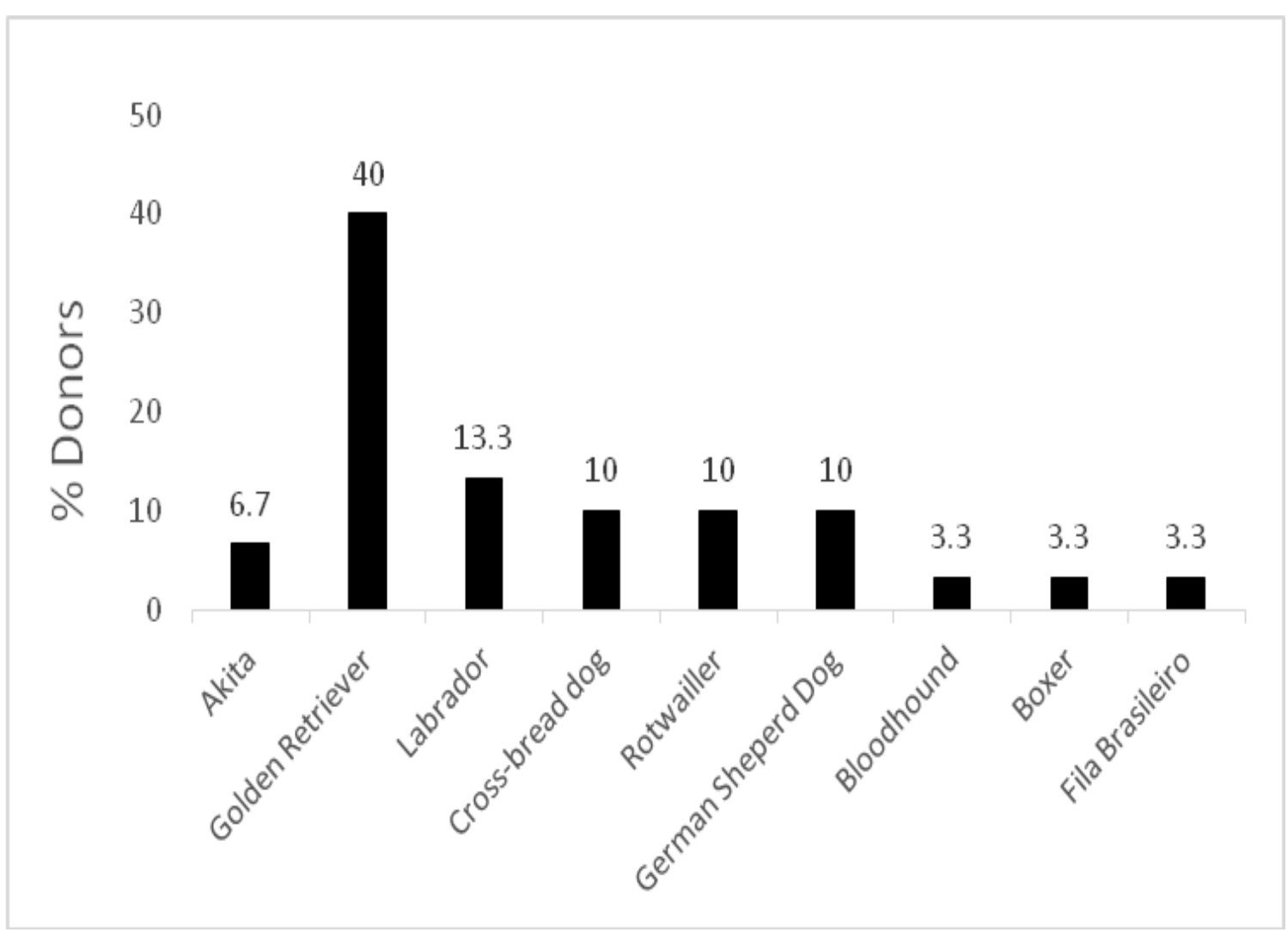

Figure 1. Percentage of donor animals in relation to the breed.

The animals were healthy on physical examination and had no laboratory abnormalities. They all tested negative for Leishmania sp., as well as the PCR tests for Erlichia sp. and Babesia sp. Both the VG and
HB of the donors (Table 1) were within the reference values for the species (37\% to $55 \%$ and $12 \mathrm{~g} / \mathrm{dl}$ to $18 \mathrm{~g} / \mathrm{dl}$, respectively), in which all donors had a VG above $42 \%$ (Weiss and Wardrop, 2010).

Table 1. Average and standard deviations for the variables observed in the total blood, red blood cell concentrate and red blood cell concentrate after the storage period. Londrina, 2016

\begin{tabular}{ccc}
\hline Stage & Variable & Average \pm SD \\
\hline & Volume $(\mathrm{ml})$ & $410.73 \pm 43.95$ \\
Total Blood & VG $(\%)$ & $39.56 \pm 4.63$ \\
& HB $(\mathrm{g} / \mathrm{dl})$ & $13.52 \pm 1.50$ \\
& Volume $(\mathrm{ml})$ & $299.77 \pm 30.08$ \\
Red Blood Cell Concentrate (Triple Bag with & VG $(\%)$ & $60.87 \pm 2.60$ \\
SAG-M) & HB $(\mathrm{g} / \mathrm{dl})$ & $20.57 \pm 0.93$ \\
& Hemolysis $(\%)$ & $0.09 \pm 0.07$ \\
& HBCH $(\mathrm{g} / \mathrm{unit})$ & $61.7 \pm 8.00$ \\
& & \\
Red Blood Cell Concentrate after storage & $\mathrm{VG}(\%)$ & $57.55 \pm 3.01$ \\
(Triple Bag with SAG-M) & $\mathrm{HB}(\mathrm{g} / \mathrm{dL})$ & $20.30 \pm 0.89$ \\
& $\mathrm{Hemolysis}(\%)$ & $0.20 \pm 0.12$ \\
& $\mathrm{HBCH}(\mathrm{g} / \mathrm{unit})$ & $60.90 \pm 7.65$
\end{tabular}

VG: Globular volume (\%); HB: Hemoglobin (g/dl); Hemolysis: Percentage of hemolysis (\%); HBCH: Hemoglobin of red blood cell concentrate (g/unit). 
In this study, bags with a volume of less than $300 \mathrm{~mL}$ were not used following the instructions of the bag manufacturer (Fresenius ${ }^{\circledR}$ ). There was a variation from $304 \mathrm{~mL}$ to $455 \mathrm{~mL}$ of blood due to the movement of the animal and due to the loss of access or a decrease of blood flow during the drawing. In medicine, according to RDC $\mathrm{N}^{\circ} 34$ of June 11th, 2014 of the MS, total blood bags with a volume less than $300 \mathrm{~mL}$ should be ignored. For bags with a volume between $300 \mathrm{~mL}$ and $404 \mathrm{~mL}$, only the red blood cell concentrate should be used and the plasma disposed.

In the hemoglobin concentrate bags with SAG$\mathrm{M}$, for the volumes below $320 \mathrm{~mL}$, the hemoglobin should be evaluated in the red cell concentrate, which should be greater than $45 \mathrm{~g} / \mathrm{unit}$ for the bag to be accepted for use (Brasil, 2014). In this study, the $\mathrm{CH}$ volume ranged from $231 \mathrm{~mL}$ to $358 \mathrm{~mL}$, and the hemoglobin from the red blood cell concentrate was higher than $47.52 \mathrm{~g} / \mathrm{unit}$ in all analyzed bags (averages in Table 1).

Furthermore, we evaluated whether the volume of the red blood cell concentrate influenced the $\mathrm{GV}$, total HB, hemolysis percentage and hemoglobin (g/unit). We observed that the volume significantly influenced the VG, total $\mathrm{HB}$ and hemoglobin g/unit result, such that the higher volume bags had higher VG (Figure 2), total HB (Figure 3) and hemoglobin g/unit (Figure 4) values. The volume did not significantly influence the percentage of hemolysis (data not shown). Ferreira et al. (2014) also did not observe a significant relation between the volume and hemolysis percentage of the red blood cell concentrate.

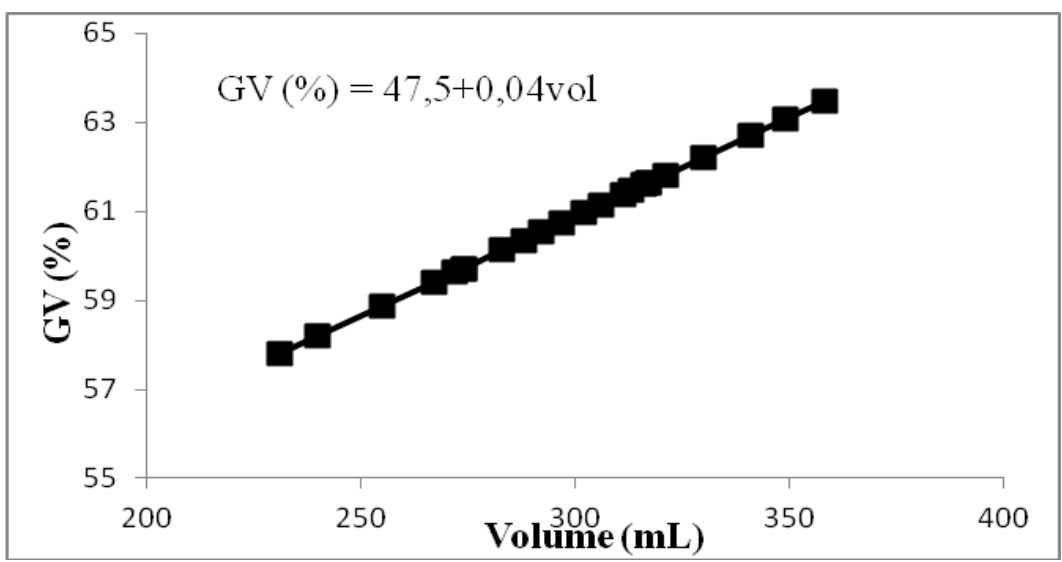

Figure 2. Regression analysis of the globular volume (\%) in relation to the volume of the red cell concentrate bags.

GV: Globular volume (\%) of the red cell concentrate with SAG-M after centrifugation; $\mathrm{P}=0.003$.

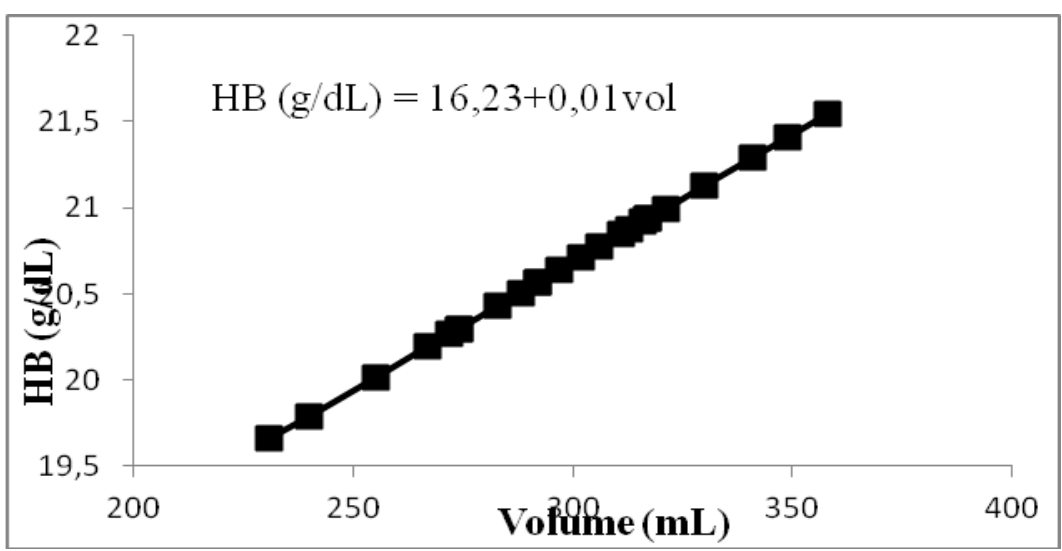

Figure 3. Regression analysis of the total hemoglobin $(\mathrm{g} / \mathrm{dL})$ in relation to the volume of the red blood cell bags.

HB: Hemoglobin of the red blood cell concentrate with SAG-M after centrifugation; $\mathrm{P}=0.007$. 


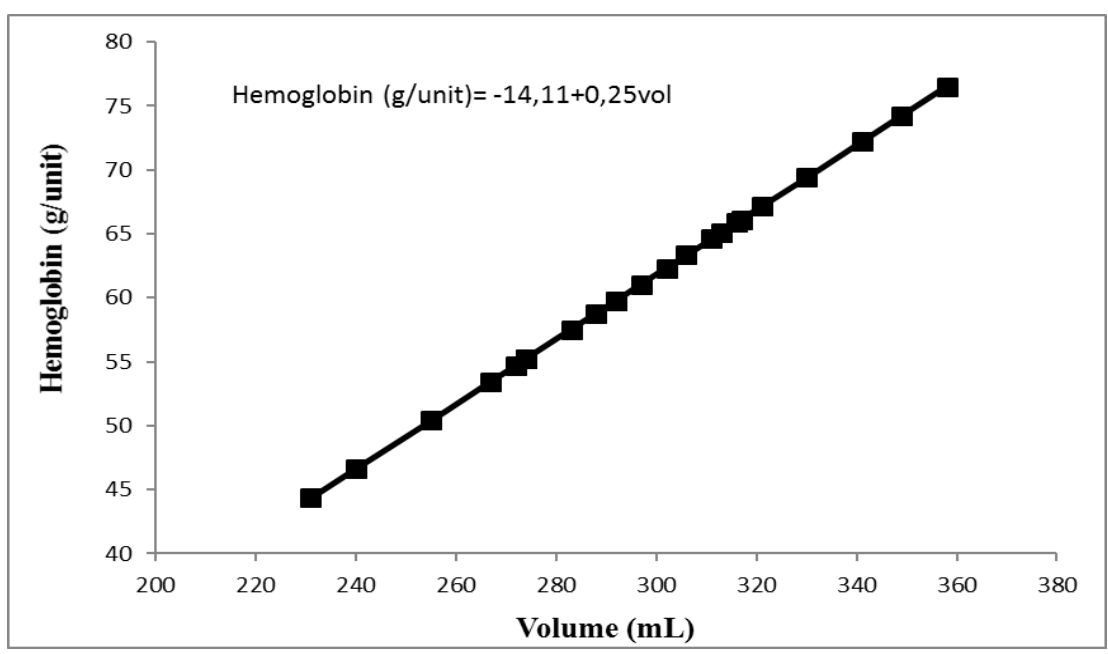

Figure 4. Hemoglobin regression analysis (g/unit) in relation to the volume of red blood cell concentrate. $\mathrm{P}<0.001$.

The volume of red blood cell concentrate significantly influenced the VG, total $\mathrm{HB}$ and hemoglobin (g/unit) because, after centrifugation, the plasma was withdrawn, and thus, the larger the volume of the bag, the greater the percentage of its globular volume. This means more red blood cells were mixed with $100 \mathrm{~mL}$ of the preservative solution, decreasing the dilution and resulting in higher values of the studied variables.

The centrifugation protocol used $4200 \mathrm{x}$ g for 10 minutes at $22^{\circ} \mathrm{C}$, with an acceleration setting of nine and a deceleration setting of five and obtained the total $\mathrm{VG}$, total $\mathrm{HB}$, hemolysis percentage and hemoglobin (g/unit) of the $\mathrm{CH}$ were satisfactory (Table 1). Therefore, this protocol was standardized for the separation of the dogs' red blood cell concentrate. There are currently several protocols for total blood centrifugation of dog blood (Ferreira et al., 2014). Feldman and Sink (2008) recommend centrifugation at $5000 \mathrm{x} \mathrm{g}$ for 5 minutes at a temperature between $1^{\circ} \mathrm{C}$ and $6^{\circ} \mathrm{C}$. Wardrop et al. (1997) used a centrifugation of $4200 \mathrm{x} \mathrm{g}$ for 6 minutes at $4^{\circ} \mathrm{C}$ and observed an average globular volume of $63 \%$ and a hemolysis percentage of $0.07 \%$. The small variation of the results of the authors mentioned above, and of this present study, may be due to the time of centrifugation, which, in this study, was longer (10 minutes). The centrifugation of total blood is a critical step, which can lead to hemolysis. According to Ferreira et al. (2014), higher velocities and centrifugation times increase the percentage of hemolysis. For Sakuma et al. (2011), each blood bank should standardize its own centrifugation protocol, provided that there is control of the quality of the blood products.

In humans, the maximum storage time is 42 days, as required by Health Ministry (Brasil, 2014). In veterinary medicine, there are no established rules regarding storage time, and the bags are stored from 28 to 35 days, depending on the preservative solution and type of refrigerator used (Wardrop, 1995; Obrador et al., 2015). The bags in this study were stored on average for $( \pm$ DP) $8.83 \pm 6.73$ days.

The Health Ministry recommends that quality control should be performed at $1 \%$ of the monthly production or in 10 bags of red blood cell concentrate per month, whichever is greater. Due to the reduced number of donors and the blood stock being insufficient for the demand, the storage period of dog blood bags ends up being shorter. Therefore, it is recommended that samples for quality control analyses be collected prior to the start of blood transfusion, so that the quality of the bag can be assessed for the period in which it was stored, as well as taking advantage of the opening of the bag to collect the quality control samples (Brasil, 2014).

The influence of the storage time on variables, including the $\mathrm{VG}, \mathrm{HB}$, percentage of hemolysis (\%) and hemoglobin of the red blood cell 
concentrate (g/unit) was verified. It was observed that the storage time only had a significant effect on the percentage of hemolysis in an increasing manner (Figure 5). Tomczak et al. (2010) obtained similar results in humans, in which longer storage times led to higher hemolysis rates, whereas the hematocrit and hemoglobin did not change significantly.

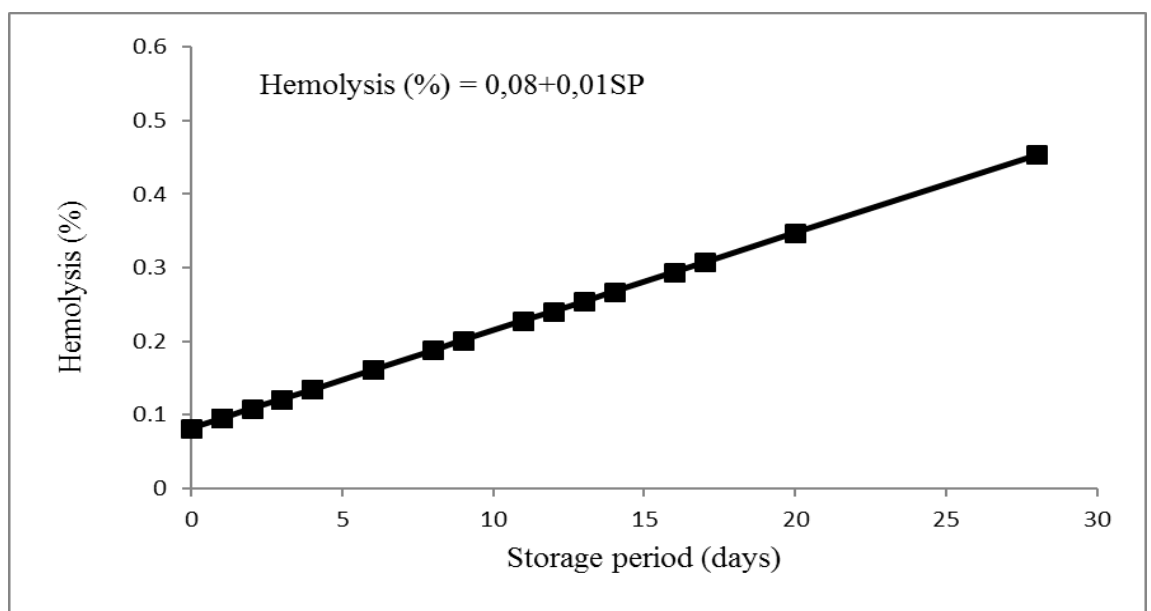

Figure 5. Regression analysis of the hemolysis percentage (\%) of the red cell concentrate bags in relation to storage time.

SP: Storage period. $\mathrm{P}<0,001$.

The average $( \pm \mathrm{SD})$ of the refrigerator minimum temperature was 2.9 \pm 1.007 , and the average maximum temperature was $4.9 \pm 1.010$. The ideal storage temperature ranges from 2 to $6^{\circ} \mathrm{C}(\mathrm{RDC}$ 34/2014), according to Scott et al. (2005), the temperature of the refrigerator can vary from 1 to $6^{\circ} \mathrm{C}$, leading to a reduction in the speed of the biochemical and molecular reactions of the red blood cells.

The quality control of the $\mathrm{CH}$ bags after the storage period was satisfactory (Table 1) given that all of the parameters evaluated were within those stipulated by the Health Ministry (Brasil, 2014 ), in which the GV must be between $50 \%$ to $70 \%$, the hemoglobin (g/unit) should be greater than $40 \mathrm{~g} / \mathrm{unit}$, and the percentage of hemolysis should not exceed $0.8 \%$.

However, legislation also recommends that $100 \%$ of the bags microbiological analyses be negative (Brasil, 2014). In this study, one of the microbiological analyses was positive in the Hemobac $\AA$ triphasic aerobic hemoculture kit, which was confirmed by culture in BHI liquid before and after the beginning of the blood transfusion, with the growth of the Staphylococcus bacterium negative coagulase. There was no growth in any Hemobac $®$ triphasic anaerobic.
There was bacterial growth in the BHI liquid of the blood bag analysis after the end of the transfusion, in which the pre-transfusion analysis in both the BHI and the aerobic three-phase Hemobac $\AA$ were negative, suggesting that there was contamination in the bag during the blood transfusion, with a 4-hour duration. The bacterium identified was coagulase-negative Staphylococcus.

After the microbiological analysis results, the subjects who received the bags with bacterial contamination were identified, and both received antibiotic therapy (Doxicillin and Enrofloxacin) due to primary disease and remained stable and uncomplicated until discharge. For Kessler et al. (2010), patients who need to receive blood transfusions are often debilitated and/or immunocompromised, so the transmission of microorganisms can lead to serious complications during the transfusion therapy.

The medical literature reports that the prevalence of bacterial contamination in blood components is $0.04 \%$ to $2 \%$, depending on the component type. This may occur even if all antisepsis care is taken at the time of collection and with the use of suitable disposable materials (Engelfriet et al., 2000). 
According to Brecher and Hay (2005), the contamination of blood bags may originate from normal skin flora, since it is very difficult to totally disinfect human skin and make it aseptic, being even more difficult in domestic animals (Stefanetti et al., 2016). In addition, the donor asymptomatic bacteremia at the time of donation or infections during the incubation or convalescence period, which are not reported by the custodian during the clinical screening, may also be the cause of contamination (Fonseca et al., 2009).

Texeira et al. (2011) observed a prevalence of $63 \%$ of Staphylococcus sp. in nine positive blood components in blood cultures. For the same authors, there were critical points during the blood collection and preparation of the blood components that were identified as susceptible to causing bacterial contamination. The steps in the production of the blood components, since the selection of donors constitutes a wide range of procedures, must be executed with attention and discipline for quality assurance.

The positive results in the microbiological analyses reaffirm the importance of the implementation of routine quality control in veterinary blood banks, because even if there is standardization in the production steps and care is taken to reduce the risks of transfusion therapy, failures can still happen. Quality control is related to the incessant demand for identifying failures in procedures and routines and, thus, allows for the repair and constant search for improvements.

\section{CONCLUSION}

The results obtained made it possible to conclude that the standardization of blood production stages involves the selection of donors until the end of storage of the blood bags and is necessary to produce quality red blood cells. The quality control of the blood bags requires hematological and microbiological laboratory tests to find possible flaws in the procedures to be repaired, increasing the transfusion safety, considering the critical condition of the patient who needs the blood transfusion.

\section{REFERENCES}

ABRAMS-OGG, A.C.G.; SCHNEIDER, A. Principles of canine and feline blood collection, processing and storage. In: WEISS, D.J.; WARDROP, K.J. Veterinary hematology. 6.ed. Iowa: Wiley-Blackwell, 2010. p.731-737.

BARROS, I.O. Avaliação da conservação do sangue total de jumentos (equus asinus) acondicionado em bolsas de sangue do tipo CPDA-1 e CPD/SAG-M. 2011. 79f. Dissertação (Mestrado em Medicina Veterinária) Universidade Federal Rural do Semi-Árido, Mossoró, RN.

BRASIL. Ministério da Saúde. Resolução RDC $\mathrm{n}^{\circ} 34$, de 11 de junho de 2014. Dispõe sobre as boas práticas no ciclo do sangue. Disponível em: <http://www.saude.rs.gov.br/upload/arquivos/car ga20170553/04145350-rdc-anvisa 34-2014.pdf>. Acessado em: 20 nov. 2016.

BRECHER, M.E.; HAY, S.N. Bacterial contamination of blood components. Clin. Microbiol. Rev., v.18, p.195-204, 2005.

DAINESE, S.M.; NUNES, D.B. Procedimentos operacionais padronizados e o gerenciamento de qualidade em centros de pesquisa. Rev. Assoc. Med. Bras., v.53, p.1-12, 2007.

ENGELFRIET, C.P.; REESINK, H.W.; BLAJCHMAN, M.A.; MUYLLE, L. et al. Bacterial contamination of blood components. Vox Sang., n.78, p.59-67, 2000.

FELDMAN B.F.; SINK, C.A. Collection, processing, storage and shipment. In: (Eds.). Practical transfusion medicine. Teton New Media: Jackson, 2008. p.14-37.

FERREIRA, R.F.R.; GOPEGUI, R.R.; MAIA, S.; MATOS, A.J.F. Laboratory analysis of canine packed red blood cells-effects of collection and processing on haemolysis, haemoglobin concentration, haematocrit and blood culture. Comp. Clin. Pathol., v.23, p.13951401, 2014.

FONSECA, L.G.; LANGHI JUNIOR, D.M.; CARVALHO, L.R.B.; MIMICA, L.M.J. et al. Avaliação da antissepsia cutânea por quatro métodos em doadores de sangue. Rev. Bras. Hematol. Hemot., v.31, p.5-8, 2009. 
FORD, R.B.; MAZZAFERRO, E.M. Emergency care. In: Kirk and Bistner's handbook of veterinary procedures and emergency treatment. 8.ed. St. Louis: Saunders, 2006. p.1-291.

KAKAIYA, R.; ARASON, C.A.; JULLEIS, J. Whole blood collection and component processing at blood collection centers. In: ROBACK, J.D. Technical manual. 17.ed. Bethesda: American Association of Blood Banks, 2011. p.187-226.

KESSLER, R.J.; RANKIN, S.; YOUNG, S.; O'SHEA, K. et al. Pseudomonas fluorescens contamination of a feline packed red blood cell unit and studies of canine units. Vet. Clin. Pathol., v.39, p.29-38, 2010.

MARCHI, M.N.A.; MARTINS, R.R.; PEREIRA, P.M. Controle de qualidade de bolsas de sangue total e concentrado de hemácias de cães. Rev. Ciên. Vet. Saúde Pública, v.2, p.131141, 2015.

OBRADOR, R.; MUSULIN, S.; HANSEN, B. Red blood cell storage lesion. J. Vet. Emerg. Crit. Care, v.25, p.187-199, 2015.

SAKUMA, A.; OTTOBONI, M.A.P.; SIERRA, P.C.; PEREIRA, A.F. Manual para controle de qualidade do sangue total e hemocomponentes. São Paulo: RedSang-Sibratec, 2011. p.120.

SCOTT, K.L.; LECAK, J.; ACKER, J.P. Biopreservation of blood cells: past, present and future. Transfus. Med. Rev., v.19, p.127-142, 2005.

STEFANETTI, V.; CAPPELLI, A.M.K.; CAPOMACCIO, S.; SGARIGLIA, E. et al. Detection of bacterial contamination and DNA quantification in stored blood units in 2 veterinary hospital blood Banks. Vet. Clin. Pathol., v.45, v.3, p.406-410, 2016.
TEIXEIRA, M.P.; SIMOES, M.L.M.S.; CORTES, V.F.; GRILLO, L.A.M. et al. Prevenção e controle da contaminação bacteriana de hemocomponentes. Rev. Enferm. Centro Oeste Mineiro, v.1, p.377-385, 2011.

TOMCZAK, A.C.T. Q. Estudos sobre o controle de qualidade de unidades transfusionais eritrocitárias. 2008. 96f. Dissertação (Mestrado em Ciências Farmacêuticas) - Universidade Federal do Paraná, Curitiba, PR.

TOMCZAK, A.C.T.Q.; GRILO, K.T.M.; CASTRO, J.M. et al. Estudo de métodos laboratoriais para o controle de qualidade de unidades transfusionais eritrocitárias no centro de hematologia e hemoterapia do Paraná (Hemepar), Brasil. Rev. Bras. Hematol. Hemot., v.3, p.209-2014, 2010.

TOULMOND, A.; FOUZIA, I.F.; FRESCHEVILLE, J.; JOUIN, C. Extracellular hemoglobins of hydrothermal vent annelids: structural and functional characteristics in three alvinellid species. Biol. Bull., v.179, p.366-373, 1990.

WARDROP, K.J. Selection of anticoagulantpreservatives for canine and feline blood storage. Vet. Clin. N. Am. Small Anim. Pract., v.25, v.6, p.1263-1276, 1995.

WARDROP, K.J.; TUCKER, R.L.; MUGNAI, K. Evaluation of canine red blood cells stored in a saline, adenine and glucose solution for 35 days. J. Vet. Intern. Med., v.11, p.5-8, 1997.

WEISS, D.J.; WARDROP, K.J. Schalm's veterinary hematology. 6.ed. Ames, IA: WileyBlackwell, 2010. 1232p. 